\title{
Cortistatin hyperpolarizes pancreatic beta cell membrane and reduces glucose-stimulated insulin secretion
}

\author{
Alex Rafacho*, Manuel Castellano-Muñoz, Paloma Alonso-Magdalena, Esperanza Irles, Melisa Bello, Jean Vetorazzi, \\ Beatriz Merino, Sergi Soriano, Pau Iborra, Antonia Ruiz, Raúl M Luque, Angel Nadal, Ivan Quesada
}

From 20th Brazilian Diabetes Society Congress

Porto Alegre, Brazil. 11-18 November 2015

\section{Background}

Cortistatin-14 (CORT) is a neuropeptide commonly expressed in inhibitory neurons of the central nervous system (CNS) with structural, pharmacological and functional similarity to somatostatin (SST). In addition to having roles in the CNS, both peptides also regulate endocrine secretion. Yet the cellular mechanisms supporting this role are not well understood.

\section{Objectives}

We studied the potential role of CORT in pancreatic beta and alpha cells function.

\section{Materials and methods}

Isolated islets and primary pancreatic beta cells from lean C57BL6 mice were used for determination of functional and electrophysiological parameters.

\section{Results}

Using insulin and glucagon secretion protocols with fresh islets isolated from C57BL6 mice, we observed that CORT reduced the glucose-stimulated insulin secretion (GSIS) in a similar magnitude from that of SST ( $<<0.01)$, an effect mediated by SST-R5 receptor. Glucagon secretion in response to $0.5 \mathrm{mM}$ glucose was completely abrogated in the presence of CORT $(\mathrm{p}<0.001)$, as well as for SST. Beta cell function were further investigated and we observed that the reduction in insulin secretion was paralleled by a decrease in the glucose-induced calcium levels observed by fura- 2 calcium imaging $(\mathrm{p}<0.001)$. As opposed to the effects on SST, the effect of CORT in

* Correspondence: alex.rafacho@ufsc.br

Universidade Federal de Santa Catarina, Florianópolis, Brazil beta cell calcium load was blocked by specific SST-R5 receptor antagonist, suggesting a higher affinity of CORT for this receptor. In addition, CORT reduced beta cell membrane potential and abolished action potential firings in perforated patch clamp experiments $(\mathrm{p}<0.001)$. CORT also diminished calcium currents in whole cell patch clamp experiments.

\section{Conclusion}

Our results suggest that the binding of CORT to SST-R5 receptors Results in beta cell hyperpolarization and impairs calcium channels activity, thus reducing the beta-cell stimulus secretion coupling.

Published: 11 November 2015

doi:10.1186/1758-5996-7-S1-A250

Cite this article as: Rafacho et al: Cortistatin hyperpolarizes pancreatic beta cell membrane and reduces glucose-stimulated insulin secretion. Diabetology \& Metabolic Syndrome 2015 7(Suppl 1):A250.

Submit your next manuscript to BioMed Central and take full advantage of:

- Convenient online submission

- Thorough peer review

- No space constraints or color figure charges

- Immediate publication on acceptance

- Inclusion in PubMed, CAS, Scopus and Google Scholar

- Research which is freely available for redistribution

Submit your manuscript at www.biomedcentral.com/submit
() Biomed Central 